\title{
PENGEMBANGAN BUKU CERITA BERGAMBAR SEBAGAI MEDIA PEMBELAJARAN
}

\author{
Windi Yuliani \\ Universitas Riau, Pekanbaru, Indonesia \\ Windi.yuliani3738@student.unri.ac.id
}

\begin{abstract}
ABSTRAK
Penelitian ini dilatarbelakangi bahwa Tingkat satuan pendidikan yang dianggab sebagai dasar penanaman ilmu untuk siswa adalah di jenjang Sekolah Dasar. Pendidikan yang ditempuh pada pendidikan dasar akan menjadi fondasi bagi proses pendidikan selanjutnya. Peneltian ini bertujuan untuk mengembangkan buku cerita bergambar "Batu Belah Batu Betangkup" dan mengetahui kelayakan buku cerita bergambar tersebut. Produk buku cerita bergambar ini dibuat menggunakan aplikasi Clip Studi Paint. Metode penelitian yang digunakan adalah model 4D terdiri dari empat tahapan yaitu Difine (Pendefenisian), Design (Perancangan), Development (Pengembangan), dan Disseminate (Penyebaran). Pengumpulan data dilakukan dengan menggunakan angket, instrumen penelitian yang digunakan telah melalui proses validasi dengan validator. Jenis data yang dihasilkan berupa data kuantitatif yang dianalisis menggunakan pedoman kriteria penilaian untuk menentukan kuantitas produk. Hasil validasi dari para ahli menyatakan bahwa produk buku cerita bergambar "Batu Belah Batu Betangkup" yang dikembangkan oleh peneliti sangat layak digunakan. Penilaian ahli desain produk dengan persentase rata-rata $88.91 \%$ dengan kategori sangat layak, penilaian ahli bahasa dengan persentase rata-rata $95.8 \%$ dengan kategori sangat layak, dan pengguna lapangan berdasarkan produk dengan persentase rata-rata $95.83 \%$ serta penilaian bahasa dengan persentase rata-rata $95.5 \%$ dengan kategori sangat layak dan uji coba produk respon siswa memperoleh $91.5 \%$ dengan kategori sangat baik. Dapat disimpulkan bahwa media buku cerita bergambar sangat layak digunakan untuk siswa Sekolah Dasar.
\end{abstract}

Kata Kunci: media pembelajaran, buku cerita bergambar

\section{DEVELOPING A PICTURE STORYBOOK AS LEARNING MEDIA}

\section{ABSTRACT}

The level of the education unit which is considered as the basis to build knowledge is the elementary school. Education pursued in elementary school becomes the foundation for the next education process. This study aimed to develop a picture storybook of "Batu Belah Batu Betangkup" and to find out the feasibility of the picture storybook. This book was made by using the cup studio paint application. The research method used was the $4 D$ model consisting of four stages, namely define, design, developt, and disseminate. The data collection was carried out through a questionnaire, which has been validated by an expert. The type of data was quantitative data which were analyzed by using the assessment criteria guidelines to determine the quantity of the product. The validation results from experts revealed that the picture storybook "Batu Belah Batu Betangkup" developed by the researcher was very suitable to be used as a learning medium. The results obtained that the average percentage from the design experts was $88.91 \%$ with a very feasible category, while the average percentage from the language experts was $95.8 \%$ with a very decent category. Then, the average percentage from field users was $95.83 \%$. After that, the average score for the language assessment was $95.5 \%$ with a very feasible category. Lastly, the result of the product trial based on the students' response was $91.5 \%$ with the very good category. Thus, the picture storybook media was very suitable to be used as learning media for elementary school students.

Keywords: instructional media, picture storybooks

\begin{tabular}{|c|c|c|}
\hline Submitted & Accepted & Published \\
\hline 11 Januari 2021 & 18 Maret 2021 & 24 Januari 2022 \\
\hline
\end{tabular}

\begin{tabular}{|l|c|c|c|}
\hline Citation & $:$ & $\begin{array}{c}\text { Yuliani, W. (2021). Pengembangan Buku Cerita Bergambar Sebagai Media Pembelajaran. Jurnal PAJAR (Pendidikan } \\
\text { dan Pengajaran), 6(1), 76-84. DOI : http://dx.doi.org/10.33578/pjr.v6i1.8276. }\end{array}$ \\
\hline
\end{tabular}

\section{PENDAHULUAN}

Perkembangan ilmu pengetahuan dan teknologi telah membawa perubahan yang cepat disegala bidang, terutama dibidang pendidikan. Bidang pendidikan, lembaga dituntut meningkatkan kualitas Sumber Daya Manusia (SDM) demi terwujudnya manusia-manusia Indonesia yang sesuai dengan UU No. 20 Tahun 2003 tentang Sistem Pendidikan Nasional, menyatakan bahwa Pendidikan Nasional bertujuan mengembangkan potensi siswa agar menjadi manusia yang beriman dan bertakwa kepada Tuhan Yang Maha Esa, berakhlak mulia, sehat, berilmu, kreatif, mandiri, dan menjadi warga negara yang demokratis serta bertanggung jawab.

Tingkat satuan pendidikan yang dianggab sebagai dasar penanaman ilmu untuk siswa adalah di jenjang Sekolah Dasar. Pendidikan yang ditempuh pada pendidikan dasar akan menjadi 
fondasi bagi proses pendidikan selanjutnya. Hal ini diperkuat oleh Prastowo yang menjelaskan bahwa pendidikan dasar memiliki dua fungsi utama, yaitu 1) memberikan pendidikan dasar berkaitan dengan kemampuan berfikir kritis, membaca menulis, berhitung, penguasaan dasardasar untuk mempelajari saintek, serta kemampuan berkomunikasi, dan 2) pendidikan dasar memberikan dasar-dasar untuk mengikuti pendidikan pada jenjang selanjutnya. Salah satu penunjang pendidikan dasar supaya berjalan secara optimal adalah dengan menanamkan kebiasaan membaca sejak dini. Kebiasaan membaca merupakan salah satu kunci keberhasilan seseorang dalam meraih ilmu pengetahuan dan teknologi.

Sebagai altefnatif untuk menanamkan kebiasaan membaca dan menunjang kemandirian siswa salah satunya dengan membuat seumber belajar yang menarik dan sesuai dengan perkembangan siswa SD. Sebagaimana teori belajar yang dimukakan oleh Piaget, yaitu anak usia 6 sampai 12 tahun (MI) berada pada fase operasional konkret. Anak pada fase ini berfikir atas dasar pengalaman-pengalaman langsung, dan mereka berfikir tentang objek-objek atau benda yang ia temukan secara langsung serta aktivitasaktivitas yang dapat ia lakukan dengan menggunakan benda-benda yang ia temui.

Siswa cenderung lebih tertarik dengan buku yang lebih banyak gambar serta warna daripada tulisan. Selain itu, mereka lebih senang membaca buku cerita bergambar daipada buku pelajaran karena kalimatnya yang pendek dan mudah dipahami. Buku cerita bergambar merupakan buku bacaan yang di dalamnya terdapat cerita dan disertai dengan gambar, gambar pada buku menggambarkan suasana di dalam cerita baik itu dalam bentuk dongeng, legenda ataupun cerita binatang (fabel). Mengapa buku cerita bergambar? Karena pada dasarnya menurut Nugriyantoro $(2005: 152)$ bahwa "dengan gambar-gambar cerita menarik yang dihadirkan, siswa akan membaca dengan penuh kesungguhan, mengikuti dan mencoba memahami alur gambar aksi yang dilihatnya, gambar tersebut akan menjadi salah satu daya gerak mengembangkan fantasi lewat imajinasi dan logika".
Gambar yang terdapat di dalam buku berfungsi sebagai pendukung sekaligus menyampaikan isi cerita. Karena menurut Lestari (2016:24) menyatakan bahwa "buku cerita bergambar adalah buku cerita yang disajikan dengan menggunakan teks dan ilustrasi atau gambar". Sedangkan menurut Krisnawan (2017:24) bahwa "buku cerita bergambar merupakan buku yang dibuat dengan memadukan cerita, gambar dan bahasa yang sederhana serta dikemas halaman sampul yang menarik. Sumber belajar yang menarik sangat cocok jika digunakan pada anak sekolah dasar, karena usia anak sekolah dasar berkisar antara 6-12 tahun. Pada usia tersebut anak sudah dapat berfikir secara nyata serta dapat memahami atas apa yang telah dibaca dan dilihat pada buku cerita bergambar, karena buku cerita bergambar dapat dilihat dan diraba.

Fakta di atas menunjukkan bahwa siswa mengalami kesulitan membaca sehingga berdampak pada kegiatan proses pembelajaran yang tidak dapat berlangsung secara optimal. Siswa dapat memahami isi materi apabila terdapat gambar yang mendukung serta tulisan yang singkat dan jelas. Oleh karena itu, perkembangan kemampuan membaca siswa dalam proses pembelajaran harus memperoleh perhatian yang serius bagi pendidik. Sumber belajar yang lebih menarik dan sesuai dengan kemampuan berbahasa serta perkembangan siswa dapat menjadi alternatif dalam membantu kemampuan membaca siswa SD.

Oleh karena itu perlu dilakukan pengembangan buku cerita bergambar untuk pembelajaran agar lebih menarik minat siswa untuk membaca dan memudahkan guru untuk menyampaikan pembelajaran.

\section{METODE PENELITIAN}

Penelitian ini adalah penelitian pengembangan yang menggunakan model $4 \mathrm{D}$ yang terdiri dari Pendefensian, Perancangan, Pengembangan,Penyebaran (Thiagarjan, 2016). Penelitian Pengembangan (development \& research) adalah metode penelitian yang digunakan untuk menghasilkan produk tertentu dan menguji keefektifan produk tersebut (Sugiyono, 2012). Penelitian pengembangan adalah suatu proses untuk mengembangkan suatu produk baru atau 
menyempurnakan produk yang sudah ada yang dapat dipetanggungjawabkan. Pada penelitian ini peneliti mengambangkan buku cerita bergambar "Batu Belah Batu Betangkup". Menurut Tageh, dkk (2014:xii) menyatakan bahwa "penelitian pengembangan adalah upaya mengembangkan dan menghasilkan suatu produk berupa materi, media, alat, dan stategi pembelajaran yang digunakan untuk mengatasi masalah pembelajaran kelas/laboratorium, dan bukan untuk menguji teori". Pendapat tersebut sejalan dengan pendapat Putra (2013:67) bahwa "secara sederhana R\&D bisa di defenisikan sebagai metode penelitian yang sengaja, sistematis, bertujuan/diarahkan untuk mencari dan menemukan , merumuskan, memperbaiki, mengembangkan, menghasilkan, menguji keefektifan produk, model, metode/strategi/cara, jasa prosedur bermakna.

Pengembangan buku cerita bergambar "Batu Belah Batu Betangkup" ini menggunakan model 4D yang terdiri dari empat tahapan yaitu difine, design, develop dan dessiminate. Jenis data yang digunakan adalah data kuantitatif berupa skor penilaian yang diberikan oleh validator terhadap buku cerita bergambar yang dikembangkan. Data hasil penelitian berupa hasil penilaian validasi yang dilakukan dengan 1 ahli media, 1 ahli bahasa, dan 1 orang guru sebagai ahli lapangan.

Aspek penilaian yang dinilai oleh ahli dibuat dalam skala likert dengan skor 1-4. Dengan meenggunakan skala ini dapat memberikan kebebasan bagi validator untuk memberikan penilaian terhadap produk yang dikembangkan. Buku cerita bergambar yang dikembangkan jika penilaian rata-rata validator dikategorikan layak dan sangat layak. Validasi media ditentukan oleh nilai rata-rata tiap aspek yang didapatkan dari validator dengan rumus:

Persentase $=\frac{\text { Skor yang diperoleh }}{\text { Skor maksimum }} \times 100 \%$

Tabel 1 Persentase Kriteria Validitas Buku Cerita Bergambar

\begin{tabular}{lll}
\hline No & Interval Rata-Rata Persentase $(\boldsymbol{\%})$ & Kategori Respon \\
\hline 1 & $76-100$ & Sangat Layak \\
\hline 2 & $51-75$ & Layak \\
\hline 3 & $26-50$ & Tidak Layak \\
\hline 4 & $0-25$ & Sangat Tidak Layak \\
\hline
\end{tabular}

Sumber:Modifkasi, (Sugiyono,2019)

\section{HASIL DAN PEMBAHASAN}

Dalam bab ini disajikan hasil penelitian pengembangan buku cerita bergambar "Batu Belah Batu Betangkup". Berdasarkan pada tahaptahap bab III, maka deskripsi hasil penelitian dibagi menjadi 4 bagian yaitu: tahap pendefenisian, tahap perancangan, tahap pengembangan dan tahap penyebaran. Validasi buku cerita bergambar "Batu Belah Batu Betangkup" dilakukan dengan 3 validator yaitu 1 ahli media, 1 ahli bahasa dan 1 guru sekolah dasar sebagai ahli lapangan. Pada proses validasi juga dilakukan perbaikan sesuai denga saran dari para validator. Setelah melakukan revisi validator akan melakukan penilaian terhadap buku cerita bergambar sesuai dengan istrumen validasi buku cerita bergambar. Berikut adalah hasil validasi ahli media, ahli bahasa, dan ahli lapangan untuk menilai kelayakan produk yang dikembangkan.

Tabel 2. Validasi Ahli Media

\begin{tabular}{cccc}
\hline No & Aspek Penilaian & $\begin{array}{c}\text { Persentase Rata- } \\
\text { Rata Aspek }\end{array}$ & $\begin{array}{c}\text { Kategori } \\
\text { Validasi }\end{array}$ \\
\hline 1 & Desain Cover & $93.75 \%$ & Sangat Layak \\
\hline 2 & Isi & $87.5 \%$ & Sangat Layak \\
\hline 3 & Desain Buku & $83.3 \%$ & Sangat Layak \\
\hline & Rata-Rata Persentase & $\mathbf{8 8 . 1 8 \%}$ & Sangat Layak \\
\hline
\end{tabular}


Pada aspek desain cover memperoleh rata-rata $93.75 \%$ dengan kategori sagat layak. Pada aspek isi buku cerita bergambar terdapat empat indikator yang digunakan untuk menilai desain produk yang dikembang oleh peneliti, pada aspek ini memperoleh nilai rata-rata $87.5 \%$ dengan kateegori sangat layak. Pada aspek desain buku memperoleh rata-rata $83.3 \%$ dengan kategori sangat layak. Rata-rata kelayakan produk buku cerita bergambar yang digunakan untuk kelayakan buku cerita bergambar "Batu Belah Batu Betangkup" keseluruhan memperoleh persentase $88.18 \%$ dengan kategori sangat layak.

Tabel 3. Validasi Ahli Bahasa

\begin{tabular}{cccc}
\hline No & Aspek Penilaian & $\begin{array}{c}\text { Persentase Rata-Rata } \\
\text { Aspek }\end{array}$ & Kategori Validasi \\
\hline 1 & Kesederhanaan & $100 \%$ & Sangat Layak \\
\hline 2 & Penekanaan & $91.6 \%$ & Sangat Layak \\
\hline 3 & Keseimbangan & $100 \%$ & Sangat Layak \\
\hline 4 & Keterpaduan & $91.6 \%$ & Sangat Layak \\
\hline & Rata-Rata Persentase & $\mathbf{9 5 . 8 \%}$ & Sangat Layak \\
\hline
\end{tabular}

Pada aspek kesederhanaan memperoleh presentase skor $100 \%$ dengan kategori sangat layak. Pada aspek penekanan memperoleh persentase skor $91.6 \%$ dengan kategori sangat layak. Pada aspek keseimbangan memperoleh persentase skor $100 \%$ dengan kategori sangat layak. Pada aspek keterpaduan memperoleh persentase skor $91.6 \%$ dengan kategori sangat layak. Rata-rata kelayakan bahasa yang digunakan untuk kelayakan buku cerita bergambar "Batu Belah Batu Betangkup" secara keseluruhan memperoleh persentase $95.8 \%$ dengan kategori sangat layak.

Tabel 4. Data Validasi Desain Produk Pengguna Lapangan

\begin{tabular}{cccc}
\hline No & Aspek Penilaian & $\begin{array}{c}\text { Persentase Rata- } \\
\text { Rata Aspek }\end{array}$ & Kategori Validasi \\
\hline 1 & Desain Cover & $93.75 \%$ & Sangat Layak \\
\hline 2 & Isi & $93.75 \%$ & Sangat Layak \\
\hline 3 & Desain Buku & $100 \%$ & Sangat Layak \\
\hline & Rata-Rata Persentase & $\mathbf{9 5 . 8 3 \%}$ & Sangat layak \\
\hline
\end{tabular}

Pada aspek desain cover memperoleh persentase skor $93.75 \%$ dengan kategori sangat layak. Pada aspek isi memperoleh persentase skor 93.75\% dengan kategori sangat layak. Pada aspek desain cover memperoleh skor $100 \%$ dengan kategori sangat layak. Rata-rata kelayakan media yang digunakan untuk kelayakan buku cerita bergambar "Batu Belah Batu Betangkup" keseluruhan memperoleh persentase $95.83 \%$ dengan kategori sangat layak.

Tabel 5. Data Validasi Bahasa Pengguna Lapangan

\begin{tabular}{cccc}
\hline No & Aspek Penilaian & $\begin{array}{c}\text { Presentase Rata- } \\
\text { Rata Aspek }\end{array}$ & $\begin{array}{c}\text { Kategori } \\
\text { Validasi }\end{array}$ \\
\hline 1 & Kesederhanaan & $100 \%$ & Sangat Layak \\
\hline 2 & Penekanan & $91 \%$ & Sangat Layak \\
\hline 3 & Keseimbangan & $100 \%$ & Sangat Layak \\
\hline 4 & Keterpaduan & $91 \%$ & Sangat Layak \\
\hline & Rata-Rata Persentase & $\mathbf{9 5 . 5 \%}$ & Sangat Layak \\
\hline
\end{tabular}


Pada aspek kesederhanaan memperoleh presentase skor $100 \%$ dengan kategori sangat layak. Pada aspek Penekanan memperoleh persentase skor $91 \%$ dengan kategori sangat layak. Pada aspek keseimbangan memperoleh persentase skor $100 \%$ dengan kategori sangat layak. Pada aspek keterpaduan memperoleh persentase skor 91\% dengan kategori sangat layak. Rata-rata kelayakan bahasa yang digunakan untuk kelayakan buku cerita bergambar "Batu Belah Batu Betangkup" secara keseluruhan memperoleh persentase $95.5 \%$ dengan kategori sangat layak.

Tabel 6. Gambar Sebelum dan Sesudah di Vallidasi

\begin{tabular}{|c|c|c|}
\hline Gambar Sebelum Validasi & Gambar Sesudah Validasi & Keterangan \\
\hline Batul Belah $\overline{\text { Batu Betangkup }}$ & 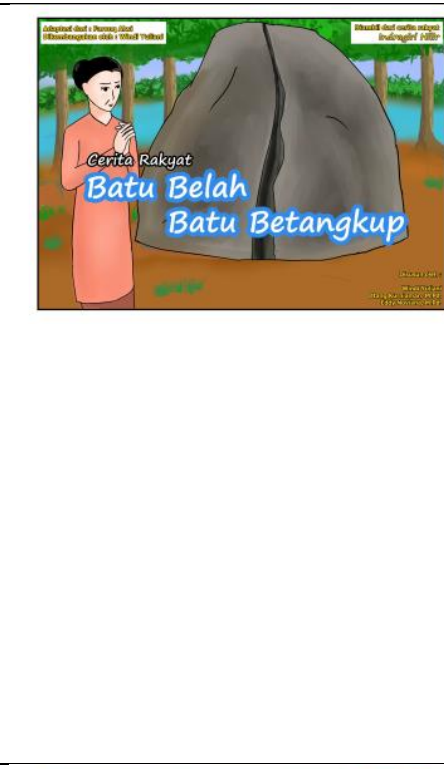 & $\begin{array}{l}\text { Gambar pada cover } \\
\text { dirubah dari bentuk } \\
\text { awal tulisan } \\
\text { berwarna kuning } \\
\text { dirubah menjadi } \\
\text { warna yang terang } \\
\text { agar lebih menarik } \\
\text { untuk siswa SD, } \\
\text { kemudian judul asal } \\
\text { cerita yang awalnya } \\
\text { terletak dibagian } \\
\text { kiri bawah, dirubah } \\
\text { posisi menjadi } \\
\text { kekanan atas dan } \\
\text { diblok dengan latar } \\
\text { putih agar lebih } \\
\text { jelas, kemudian } \\
\text { bentuk batu dibuat } \\
\text { seperti terbelah. }\end{array}$ \\
\hline \&. & 1 & $\begin{array}{lr}\text { Pada halaman 1, } \\
\text { gambar rumah } \\
\text { dirubah menjadi } \\
\text { bentuk rumah pada } \\
\text { zaman dahulu di } \\
\text { indragiri } r \text { hilir, } \\
\text { kemudian } & \text { suasana } \\
\text { sekitar rumah } \\
\text { dirubah menjadi } \\
\text { rawa-rawa. }\end{array}$ \\
\hline EN & $\frac{180}{2}$ & $\begin{array}{lr}\text { Pada halaman } 2, \\
\text { gambar } & \text { yang } \\
\text { awalnya } & \text { hanya } \\
\text { berjualan } & \text { sendiri } \\
\text { dirubah } & \text { menjadi } \\
\text { ramai agar } & \text { terlihat } \\
\text { seperti } & \text { sedang } \\
\text { berjualan dipasar. }\end{array}$ \\
\hline
\end{tabular}




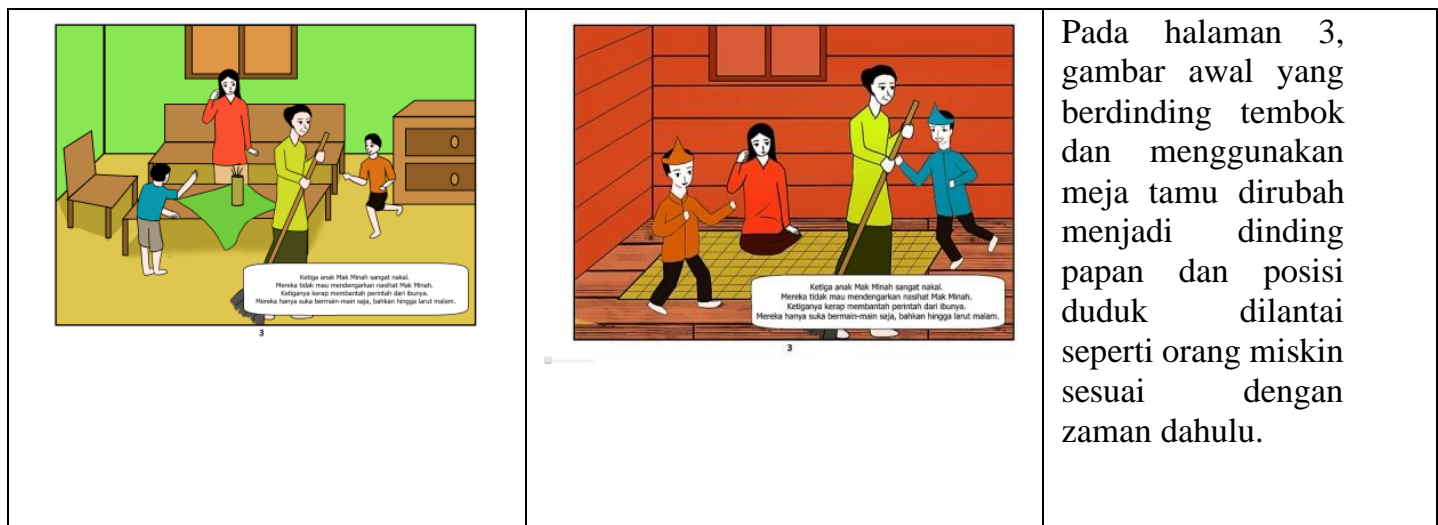

Tujuan dilakukannya revisi gambar pada buku cerita bergambar "Batu Belah Batu Betangkup" yang peneliti kembangkan sehingga layak digunakan. Perbaikan yang dilakukan yaitu merubah semua konsep yang tadinya seperti kehidupan orang kaya dirubah menjadi konsep kehhiupan orang miskin sesuai dengan kehidupan zaman dahulu diindragiri hilir.

Tabel 7. Cerita Sebelum dan Sesudah Validasi

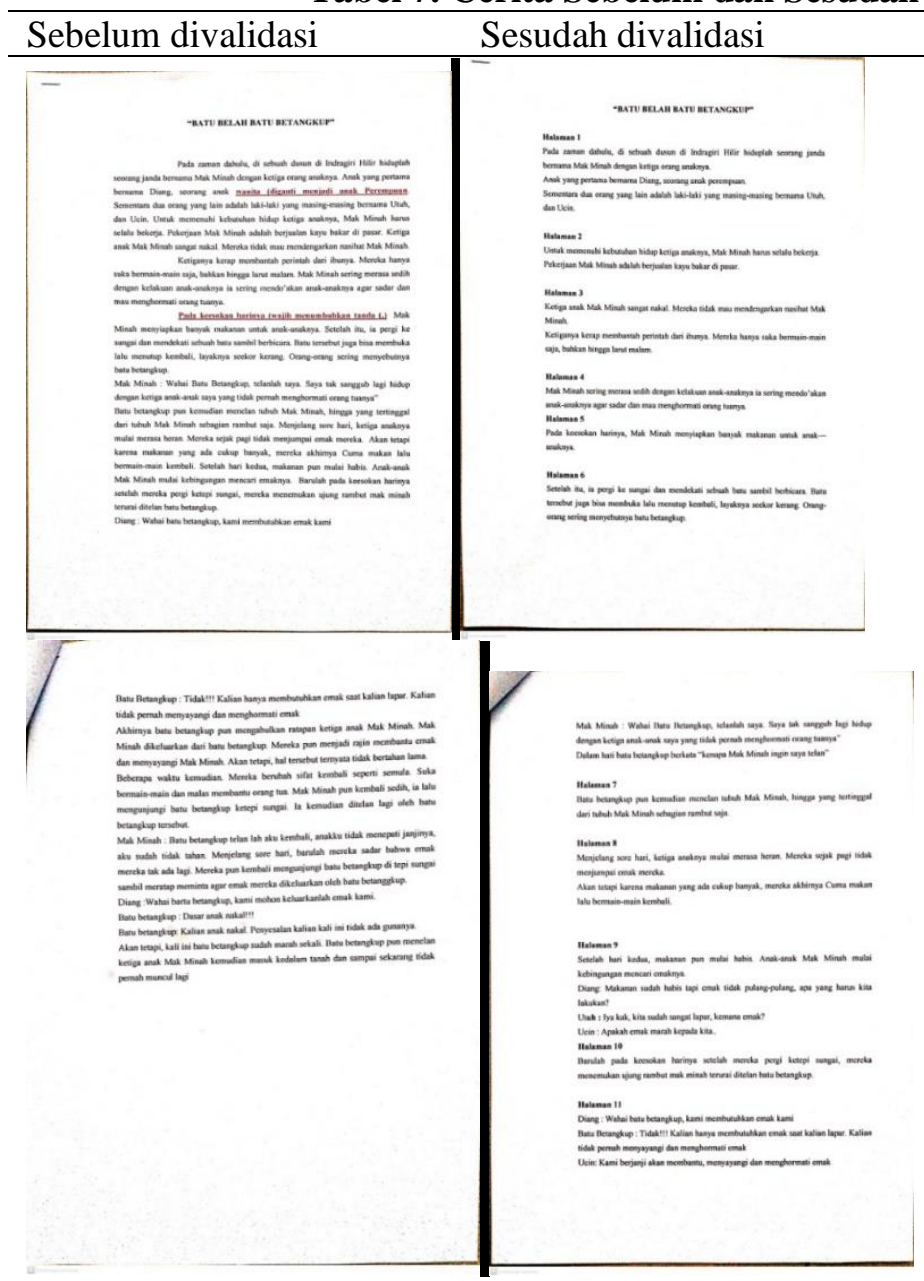




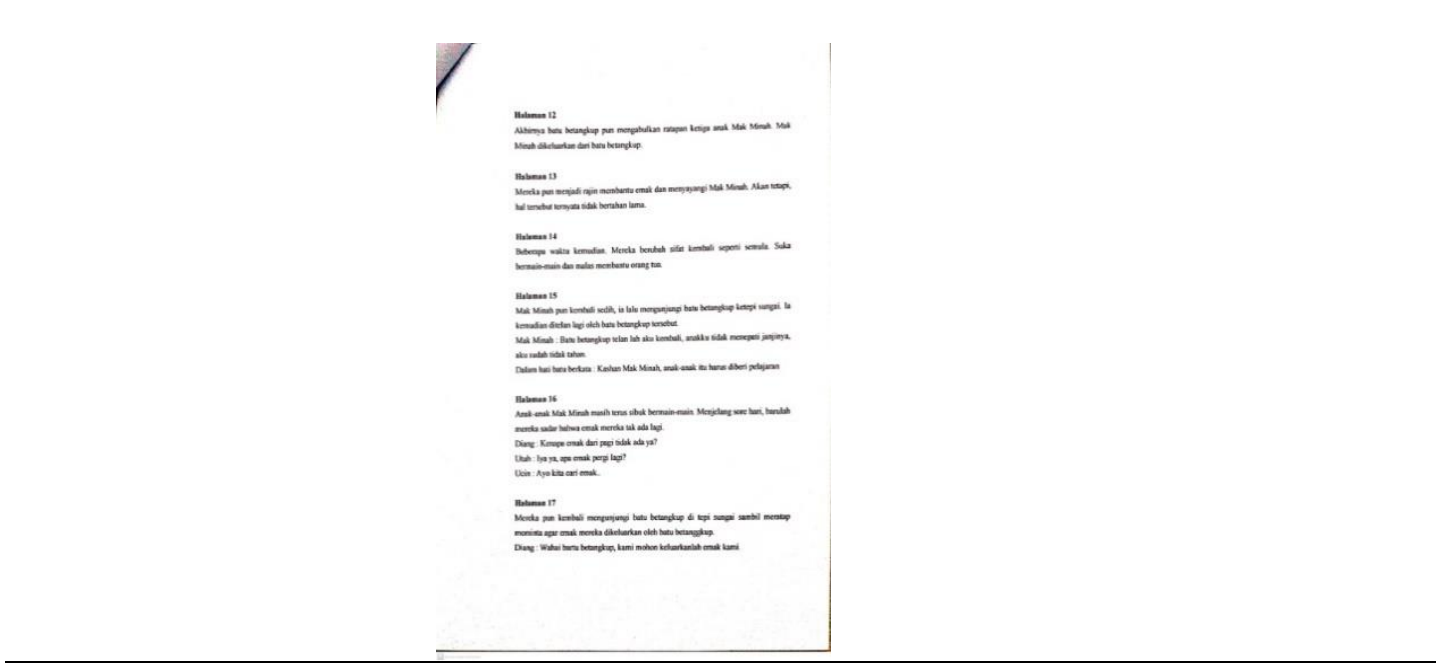

Tujuan dilakukannya revisi penulisan pada buku cerita bergambar "Batu Belah Batu Betangkup" yang peneliti kembangkan agar penulisan serta tanda baca yang terdapat pada buku sesuai untuk siswa SD.

Pada tahap ini dilakukan uji coba tebatas untuk memperoleh informasi mengenai respon dari siswa setelah menggunakan rancangan produk yang dikembangkan. Peneliti mengujicobakan terbatas produk buku cerita bergambar "Batu Belah Batu Betangkup" pada siswa sekolah dasar yang berjumlah 5 orang siswa. Beerikut ini adalah data respon siswa terhadap produk :

Tabel 8. Data Respon Siswa pada Uji Coba Terbatas

\begin{tabular}{cccc}
\hline No & Aspek Penilaian & $\begin{array}{c}\text { Persentase Rata- } \\
\text { Rata Aspek }\end{array}$ & Kategori Valodasi \\
\hline 1 & Tanggapan & $90 \%$ & Sangat Baik \\
\hline 2 & Reaksi & $93 \%$ & Sangat Baik \\
\hline & Rata-Rata Persentase & $\mathbf{9 1 . 5 \%}$ & Sangat Baik \\
\hline
\end{tabular}

Berdasarkan hasil data respon siswa terhadap buku cerita beragambar "Batu Belah Batu Betangkup" yang dikembangkan oleh peneliti diperoleh rata-rata persentase sebesar $91.5 \%$ dengan kategori sangat baik.

\section{Pembahasan}

Penelitian pengembangan merupakan rangkaian proses atau langkah-langkah dalam mengembangkan suatu produk yang efektif dan merupakan bahan-bahan pembelajaran, media, strategi pembelajaran yang digunakan untuk sisa sekolah dan bukan menguji teori. Pada penelitian ini peneliti mengembangkan buku cerita bergambar "Batu Belah Batu Betangkup". Model pengembangan yang digunakan yaitu model 4D, yang terdiri dari Pendefenisian, Perancangan, Pengembangan, Penyebaran (Thiagarjan,2016).
Yang terdiri dari 4 tahap yaitu, pendefenisian (difine), perancangan (design), pengembangan (development), dan penyebaran (disseminate).

Penelitian ini dimulai dengan tahap pendefenisian (difine), pada tahap ini yang dilakukan peneliti yaitu menganalisis cerita rakyat, cerita rakyat yang diambil oleh peneliti yaitu cerita rakyat daerah Indragiri Hilir dengan judul "Batu Belah Batu Betangkup". Setelah melakukan analisis ceita rakyat, tahap selanjutnya adalah tahap design atau perancangan. Tahap design merupakan tahap merancang produk buku cerita bergambar "Batu Belah Batu Betangkup dengan membuat dialog.

Tahap ketiga adalah tahap pengembangan (development), pada tahap ini peneliti melakukan validasi produk kepada 1 orang ahli desain produk, 1 orang ahli bahasa, 1 orang pengguna lapangan. 
Berdasarkan hasil validasi buku cerita bergambar "Batu Belah Batu Betangkup" Ahli desain produk memperoleh skor $88.18 \%$ dengan kategori sangat layak, hasil validasi ahli bahasa memperoleh persentase $95.8 \%$ dengan kategori sangat layak, hasil validasi pengguna lapangan berdasarkan kelayakan produk memperoleh persentase $95.83 \%$ dengan kategori sangat layak, dan hasil validasi pengguna lapangan berdasarkan kelayakan bahasa 95.5\% dengan kategori sangat layak. Sehingga berdasarkan hasil tersebut secara keseluruhan Buku Cerita Bergambar Batu Belah Batu Betangkup yang dikembangkan peneliti sangat layak digunakan pada siswa Sekolah Dasar. Setelah melakukan validasi, tahap selanjutnya adalah melakukan uji coba terbatas untuk mengetahui respon siswa terhadap prosduk yang dikembangkan. Uji coba produk ini dilakukan kepada siswa sekolah dasar sebanyak 5 orang. Berdasarkan hasil data respon siswa terhadap buku cerita bergambar "Batu Belah Batu Betangkup" yang dikemabangkan oleh peneliti mendapat respon yang sangat baik dari siswa yang menggunakan produk ini.

Tahap keempat adalah penyebaran (Disseminate), pada tahap iini dilakukan penyebaran buku cerita bergambar "Batu Belah Batu Betangkup" dengan memberikan cetakan kepada guru kelas IV agar buku cerita bergambar "Batu Belah Batu Betangkup" yang dikembangkan oleh peneliti dapat digunakan oleh guru. Pengembangan buku cerita bergambar ini juga sangat erat hubungannya dengan anak-anak. Hal tersebut dikarenakan agar lebih mempermudah anak dalam memahami isi sebuah bacaan yang mereka baca.

\section{SIMPULAN DAN REKOMENDASI}

Berdasarkan hasil analisis data dan pembahasan maka dapat disimpulkan bahwa: Pengembagan buku cerita bergambar sebagai media pembelajaran berhasil dikembangkan meliputi tahap difine (pendefenisian), design (perancangan), development (pengembangan), dessiminate (penyebarluasan). Pada tahap difine (pendefenisian) peneliti melakukan analisis kurikulum, analisis peserta didik (siswa), analisis materi dan analisis cerita rakyat. Pada tahap design (perancangan) peneliti merancang desain buku cerita bergambar. Tahap development (pengembangan) ini diperoleh produk akhir berupa buku cerita bergambar yang telah divalidasi dan dinilai oleh ahli media, ahli bahasa dan guru, serta diuji cobakan dan direspon oleh 5 siswa. Pada tahap dessiminte (penyebarluasan) produk yang sudah dicetak kemudian diberikan kepada guru di SDN 147 Pekanbaru agar dapat dimanfaatkan. Pengembangan buku cerita bergambar sebagai media pembelajaran sangat layak digunakan berdasarkan ahli desain produk memperoleh skor persentase $88.18 \%$, ahli bahasa memperoleh skor persentase $95.8 \%$, pengguna lapangan berdasarkan kelayakan produk memperoleh skor $95.83 \%$, dan penggunaan lapangan berdasarkan kelayakan bahasa memperoleh skor $95.5 \%$.

Peneliti selanjutnya perlu dilakukan penelitian lebih lanjut untuk memperoleh data, masukan dan saran yang lebih banyak untuk mendapatkan hasil yang maksimal. Guru dapat menggunakan penelitian ini sebagai masukan dalam mengebangkan buku cerita bergambar untuk siswa sekolah dasar.

\section{DAFTAR PUSTAKA}

Krisnawan., \& Hilarius A. (2017). Pengembangan Buku Cerita Bergambar Berbasis Pendidikan Anti Korupsi Untuk Pembelajaran Membaca Siswa Kelas II B SD Negeri Dayuharjo Tahun Pelajaran 2016-2017, Skripsi, Universitas Sanata Dharma, Yogyakarta.

Lestari, M. D. (2016). Pengembangan Buku Cerita Untuk Menanamkan Karakter Peduli Sosial, Jujur dan Tanggung Jawab Siswa Sekolah Dasar Kelas Rendah, Skripsi, Universitas Sanata Dharma, Yogyakarrta.

Majid, A. (2014). Pembelajaran Tematik Terpadu. Bandung: PT Remaja Rosdakarya

Nugriyantoro, B. (2005). Sastra Anak Pengantar Pemahaman Dunia Anak. Yogyakarta : Gadjah Mada University Press

Putra, S. R. (2013). Desain Belajar Mengajar Kreatif Berbasis Sains. Yogyakarta : Diva press

Sugiyono. (2012). Metode Penelitian Kuantitatif, Kualitatif dan $R \& D$. Bandung : Alfabeta. 
Sugiyono. (2009). Metode penelitian bisnis: pendekatan kuantitatif, kualitatif, dan $R \&$ $D$. Bandung: Alfa beta.

Sugiyono. (2015). Metode Penelitian dan Pengembangan: reseacrh and development untuk bidang pendidikan, manajemen, dan sosial, dan teknik. Bandung : Alfabeta

Tageh, M, dkk. (2014). Model Penelitian Pengembangan. Yogyakarta : Graha Ilmu

Thiagarajan, S. (2016). Instructional Development for Training Teachers of Exceptional Children A Source Book. Indiana : ERIC 